DOI: https://doi.org/10.47405/mjssh.v7i1.1256

\begin{tabular}{|c|c|}
\hline 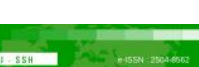 & Malaysian Journal of Social Sciences and Humanities (MJSSH) \\
\hline $\begin{array}{l}\text { Malaysian Journal of } \\
\text { Socai sciences and }\end{array}$ & Volume 7, Issue 1, January 2022 \\
\hline (MJ-sSH) & e-ISSN : 2504-8562 \\
\hline & $\begin{array}{l}\text { Journal home page: } \\
\text { www.msocialsciences.com }\end{array}$ \\
\hline
\end{tabular}

\title{
Pengenalpastian Corak Taburan Penyakit Tuberkulosis Menggunakan Sistem Maklumat Geografi (GIS) di Mukah, Sarawak
}

\author{
Oliver Valentine Eboy' ${ }^{1}$ Kho Shiau Hong1 \\ 1Program Geografi, Fakulti Sains Sosial Dan Kemanusiaan, Universiti Malaysia Sabah (UMS), Malaysia \\ Correspondence: Kho Shiau Hong (inorilyona@gmail.com)
}

\begin{abstract}
Abstrak
Penyakit tuberculosis merupakan salah satu penyakit berjangkit yang boleh disebar melalui udara. Ia dijangkit oleh bakteria Mycobacterium apabila seseorang individu bersin atau batuk. Penyakit ini boleh sembuh dengan mengikuti rawatan yang telah dijalankan dengan mengambil tempoh masa yang panjang. Sistem survelan penting dalam pengawalan dan pencegahan penyakit tuberkulosis dengan mengaplikasikan GIS ke dalam bidang kesihatan. Dengan itu, kajian ini bertujuan untuk mengenal pasti corak taburan tuberkulosis di daerah Mukah. Kajian ini melibatkan tiga teknik analisis GIS iaitu analisis Mean Center, analisis Hot Spot dan analisis Moran'I. Kajian ini melibatkan data tuberkulosis tahun 2017 bagi kawasan daerah Mukah. Hasil kajian ini mendapati bahawa kes tuberkulosis bagi golongan lelaki adalah lebih tinggi berbanding dengan golongan perempuan. Sehubungan dengan itu, berdasarkan taburan tuberkulosis mendapati bahawa kes tuberkulosis adalah tinggi di kawasan bandar berbanding di luar bandar Mukah. Analisis mean center telah menunjukkan pusat purata terletak kawasan pinggir bandar. Taburan bagi penyakit ini adalah bersifat rawak. Kawasan titik panas terletak berhampiran dengan bandar Mukah. Hasil paparan daripada teknik analisis GIS menunjukkan bahawa ia adalah penting sebagai salah satu tindakan kepada pakar perancang dalam menentukan aktiviti pencegahan penyakit tuberkulosis di daerah Mukah.
\end{abstract}

Kata kunci: Sistem Maklumat Geografi (GIS), Penyakit tuberkulosis, Analisis pusat purata, Analisis Hotspot, Analisis Moran's I

\section{Identification of tuberculosis disease distribution patterns using geographic information system (GIS) in Mukah, Sarawak}

\begin{abstract}
Tuberculosis is a contagious diseases that easily spread through air as it transmitted by Mycobacterium bacteria when sneeze and cough. This disease needs a long period of treatment to recover and therefore an important surveillance system is required in controlling and preventing tuberculosis disease through GIS. Thus, this study aims to identify the pattern of tuberculosis distribution using GIS in Mukah district in Sarawak. Mukah district was chosen as it recorded one of the highest tuberculosis cases in Malaysia. Three types of GIS analysis involved, namely mean center, hot spot and Moran's I was used in this study. Based on the study, tuberculosis cases for male patients were recorded higher than female and most of the cases occurred in urban areas compared to rural area in Mukah. Using the mean centre analysis, the concentration centre located a suburban areas as this was also indicated by Hotspot analysis. Lastly, this paper has proven that GIS plays an important role in planning and prevention of Tuberculosis disease.
\end{abstract}


Keywords: Geographic Information System (GIS), Tuberkulosis disease, Mean center analysis, Hotspot analysis, Moran's I analysis

\section{Pengenalan}

Penyakit tuberkulosis merupakan penyakit berjangkit yang tertua di dunia. Menurut WHO menyatakan bahawa pada tahun 1900 terdapat 7.5 juta kes tuberkulosis dan 2.5 juta kes kematian akibat dijangkiti oleh penyakit tersebut (Shamsul et al., 2002). Seterusnya pada awal tahun 1940-an dan 1950-an, penyakit tuberkulosis ini menjadi punca kematian utama di Malaysia (Mohd Faiz et al., 2017). Ekoran daripada itu, dianggar sejumlah 9 juta kes penyakit tuberkulosis dari seluruh dunia pada tahun 2013 dan sebanyak 1.5 juta kes kematian berpunca daripada penyakit ini (Mohd Faiz \& Jamal, 2017). Hal ini berpunca daripada kepantasan sebaran bakteria yang dikenali sebagai Mycobacterium Tuberculosis melalui udara (WHO, 2018).

Akibat daripada kejadian tersebut, banyak usaha yang telah dilakukan oleh pihak kerajaan ataupun badan bukan kerajaan untuk mengurangkan kejadian kes tuberkulosis di Malaysia. Pada tahun 1961, Program Kawalan Tuberkulosis Kebangsaan (PKTK) telah diperkenalkan oleh pihak kerajaan Malaysia (Mohd Faiz et al., 2017). Tujuan program ini adalah untuk mengawal dan mengurangkan kes kejadian tuberkulosis di Malaysia. Pengawalan melalui perubatan juga diperkenalkan iaitu Calmette Guerin Vaccine (BCC) oleh WHO bagi mengelakkan penularan penyakit tuberkulosis (Yuan-qiang et al., 2015). Pada tahun 1973, kerajaan telah menubuhkan pasukan pengawalan tuberkulosis di setiap negeri. Seterusnya pada peringkat global pula, Pertubuhan Kesihatan Sedunia (WHO) telah memperkenalkan skim rawatan iaitu program Directly Observed Therapy Short Course (DOTS) bagi memastikan pesakit tuberkulosis sembuh sepenuhnya (Akaninyene, 2013).

Sehubungan dengan itu, penyakit tuberkulosis haruslah dikawal dengan bergantung kepada sistem tindakan yang berkesan. Sistem tindakan yang berkesan bergantung kepada sistem survelan penyakit yang sistematik (Shamsul et al., 2002). Sistem survelan adalah berfungsi sebagai sistem pemberian maklumat untuk sesuatu tindakan dalam pengawalan penyakit berjangkit. Sistem survelan ini penting bagi penggubalan polisi, perancangan, ramalan, penambahbaikan program pencegahan dan pengawalan penyakit berjangkit (Shamsul et al., 2002).

Zaman teknologi maklumat, telah memudahkan aktiviti sistem survelan dijalankan kerana ia boleh diganti dengan penggunaan peralatan elektronik. Kewujudan Sistem Maklumat Geografi (GIS) yang bertindak sebagai satu aset elektronik sistem survelan mampu menerangkan dan memahami perubahan ruang dalam pelbagai bidang termasuk bidang kesihatan (Norazman al., 2018). Hal kerana ia mampu menganalisis keperluan perkhidmatan kesihatan, hubungan dan peningkatan mutu perkhidmatan kesihatan di sesebuah lokasi. Penggunaan GIS juga lebih baik berbanding dengan pemetaan manual kerana kebolehannya dalam menghasilkan paparan yang cepat dan mudah serta dapat mencapai penyelesaian dalam suatu permasalahan yang melibatkan ruang (Eboy, 2017). Trevor (2008) pula menyatakan bahawa GIS merupakan satu peralatan yang penting dan bernilai kepada ahli geografi kesihatan. Hal ini disebabkan penggunaan perisian ini boleh digunakan untuk menjalankan analisis berkaitan dengan maklumat bidang kesihatan untuk mengenal pasti keputusan dan peruntukan terhadap perkhidmatan kesihatan (Pearce, 2007). Penggunaan perisian GIS dalam bidang kesihatan membolehkan penyelidik melihat kepada faktor ruangan yang mempengaruhi taburan penyakit. Terdapat banyak kajian lepas menggunakan teknik analisis GIS dalam mengenal pasti taburan penyakit sama ada di peringkat antarabangsa ataupun di Malaysia seperti Narimah et al. (2014), Ratchaphon et al. (2014), Yun Xia et al. (2015), Haikun Qian et al. (2016), Mohd Hazrin et al. (2016), Kefyalew et al. (2017) dan Yih Yuan et al. (2017). Kebanyakan kajian lepas dijalankan di kawasan yang mempunyai kepadatan penduduk yang tinggi berbanding di kawasan yang kurang kepadatannya seperti di Mukah. Seterusnya, kebanyakan kajian lepas mengkaji mengikut trend masa dengan menggunakan data dalam tempoh empat hingga lima tahun. Tambahan lagi kajian dahulu GIS bagi paparan stastik sahaja (Ratchaphon et al., 2014). Kebaikan penggunaan perisian GIS adalah mampu wujudnya pangkalan data 
dan menghasilkan pelbagai jenis analisis paparan peta yang bertindak sebagai salah satu tindakan sistem survelan yang penting terhadap pengawalan penyakit tuberkulosis. Oleh itu, kertas kajian ini telah dilaksanakan dengan menggunakan teknik analisis GIS untuk mengenal pasti corak taburan penyakit tuberkulosis di daerah Mukah.

\section{Faktor-Faktor Penyebaran Penyakit Tuberkulosis}

Faktor pertama penyebaran penyakit tuberkulosis adalah migrasi (WHO, 2015; Androula \& Helena, 2017). Seseorang individu bergerak dari satu tempat ke tempat yang lain dengan pelbagai tujuan. Golongan ini mempunyai risiko yang tinggi untuk menjangkiti dan dijangkiti oleh individu lain. Ini telah dibuktikan oleh Kefyalew et al. (2017), menyatakan bahawa kawasan perindustrian merupakan kawasan yang mempunyai tumpuan tinggi bagi migrasi terutamanya golongan pekerja kerana memerlukan tenaga kerja yang banyak. Tambahan pula, kawasan perindustrian terletak berjauhan dengan pusat perkhidmatan kesihatan menyebabkan penyebaran penyakit tuberkulosis yang tinggi di kalangan pekerja terutamanya pekerja lelaki.

Faktor kedua adalah disebabkan oleh unsur-unsur iklim. Unsur-unsur iklim terdiri daripada cahaya matahari, kelembapan, pemeluwapan dan suhu mempunyai kaitan yang rapat dengan penyebaran penyakit tuberkulosis (Fernanda et al., 2017). Kadar sinaran cahaya matahari yang tinggi, meningkatkan kadar sinaran UV di ruang udara (Malcolm, 2014). Apabila sinaran tersebut terkena dengan kulit manusia maka wujudnya vitamin D di badan manusia. Vitamin D ini berupaya mengelakkan manusia daripada dijangkiti oleh penyakit tuberkulosis. Keadaan ini menyebabkan risiko rendah dijangkiti oleh penyakit tuberkulosis. Sebagai contoh di negara England mempunyai kes penyakit tuberkulosis yang tinggi pada musim sejuk disebabkan kekurangan sinaran matahari pada musim tersebut (Fernanda et al., 2017). Tambahan lagi, kadar kelembapan dan pemeluwapan saling mempengaruhi jumlah bilangan kes tuberkulosis. Di Brazil, kadar kelembapan di antara 31 peratus hingga 69 peratus dan kadar pemeluwapan yang kurang daripada $1 \mathrm{~mm}$ menyebabkan jumlah kes tuberkulosis mencapai 95.8 peratus (Fernanda et al., 2017). Seterusnya, suhu yang tinggi menyebabkan peningkatan kes tuberkulosis. Sebagai contoh di Brazil, suhu di antara 200c hingga 230c menyebabkan peningkatan kes tuberkulosis ke 72.4 peratus. Keadaan ini jelas menunjukkan bahawa faktor unsur iklim mempengaruhi penyakit tuberkulosis.

Faktor ketiga dalam mempengaruhi penyebaran tuberkulosis adalah pencemaran udara. Ruang udara yang mempunyai elemen ampaian seperti karbon dioksida, karbon monoksida, sulfur dioksida, dan nitrogen dioksida yang tinggi menggalakkan peningkatan kes tuberkulosis (Fernanda et al., 2017). Di Korea Selatan, mendapati semakin tinggi kadar kepekatan elemen ampaian menyebabkan peningkatan kes tuberkulosis sebanyak 1.27 kes (J. Kim, 2014). Ini menunjukkan bahawa pencemaran udara mempengaruhi jumlah kejadiaan tuberkulosis. Secara tidak langsung menunjukkan bahawa faktor pencemaran udara mempunyai kait rapat dengan taburan penyakit tuberkulosis. Ekoran daripada itu, penyakit tuberkulosis turut mempengaruhi tahap kesihatan penduduk Malaysia.

Selain itu, kemiskinan juga merupakan faktor penyebaran penyakit tuberkulosis (M. Muniyandi et al., 2018). Golongan pelarian dan golongan gelandangan mempunyai tahap kesihatan yang rendah disebabkan kemiskinan. Golongan ini tidak mampu mendapatkan rawatan pemeriksaan kesihatan. Tambahan pula, persekitaran kediaman yang kotor mendorong mereka berisiko tinggi dijangkiti oleh penyakit tuberkulosis. Sebagai contoh migrasi di kawasan South East Asia, Wastern Pasific, Afrika, Amerika Tengah dan Utara, Middle East dan Eastern berisiko tinggi mendapat penyakit tuberkulosis. Dalam kajian Olivia et al. (2012) telah menunjukkan bahawa golongan yang miskin mempunyai risiko tinggi iaitu sebanyak 5.5 kali ganda dijangkit oleh penyakit tuberkulosis berbanding dengan golongan yang berkemampuan. Hal ini disebabkan mempunyai indeks jisim badan yang rendah menyebabkan daya tahanan badan rendah. Keadaan ini mendorong penularan penyakit di kawasan yang mempunyai tahap kemiskinan yang tinggi. 


\section{Lokasi Kajian}

Kajian ini ditumpukan di kawasan daerah Mukah, Sarawak. Keluasan daerah penuh Mukah ini adalah seluas $2536 \mathrm{~km}$ persegi. Bahagian Mukah bersempadan dengan Sibu, Bintulu dan Sarikei (Norfazila et al, 2016). Dari segi bentuk muka bumi, daerah Mukah kebanyakannya terletak di kawasan hutan paya dan di kawasan pinggir pantai dan muara sungai. Jenis tanah yang terdapat di kawasan ini adalah terdiri daripada tanah pamah dan tanah gambut yang sangat sesuai untuk tanaman. Selain itu, aktiviti pertanian komersial seperti penanaman pokok rumbia, pokok kelapa, pokok pisang, dan sebagainya juga dijalankan oleh sebahagian besar penduduk bumiputera di daerah Mukah. Pada penduduk juga melakukan aktiviti perikanan turut giat dijalankan oleh penduduk terutamanya aktiviti penangkapan hasil laut telah menjadi sumber pendapatan penduduk daerah Mukah.

\section{Rajah 1: Peta lokasi kajian}

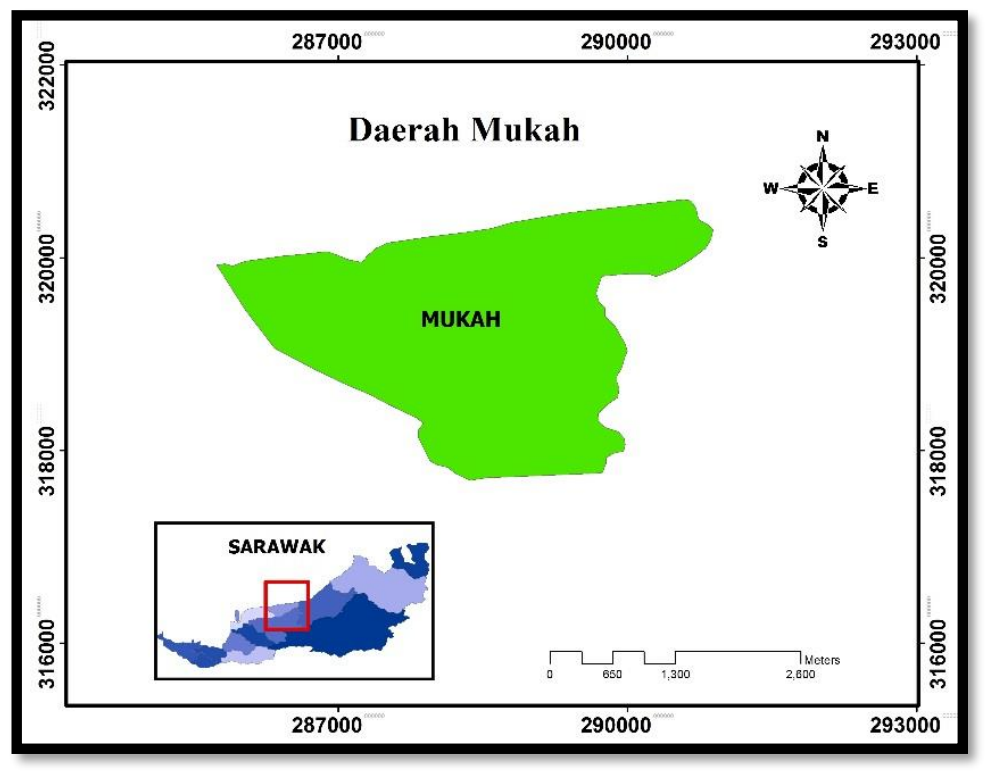

Daerah Mukah dijadikan sebagai kawasan kajian yang bersesuaian dalam kajian ini, justifikasi pemilihannya adalah kerana kes tuberkulosis yang besar iaitu mencecah sehingga melebihi 50 kes setiap tahun.

Jadual 1. Jumlah bilangan kes tuberkulosis dari tahun 2014 hingga 2017 di daerah Bahagian Mukah

\begin{tabular}{ccccc}
\hline Tahun & 2014 & 2015 & 2016 & 2017 \\
\hline Jumlah & 62 & 58 & 55 & 56 \\
\hline
\end{tabular}

Tambahan lagi, kawasan ini telah dipilih untuk menjadi status sebagai bandar pintar atau smart city menjelang tahun 2030 (Potral rasmi RECODA, 2018). Ia merupakan sebuah aktiviti pembangunan di bawah pimpinan Regional Corridor Development Authority (RECODA). Perlaksanaan ini telah disokong oleh Ketua Menteri Sarawak (Utusan Borneo, 2018). Tujuan wujudnya bandar pintar bagi menambahbaikkan kualiti perbandaran dan kehidupan penduduk di sesebuah kawasan. Salah satu elemen penting dalam kriteria smart living bagi konsep bandar pintar adalah keupayaan penduduk memperoleh perkhidmatan kesihatan bagi kesejahteraan hidup penduduk (Kok-Lim et al., 2016). 


\section{Metod Kajian}

Pendekatan yang digunakan oleh penyelidik dalam kajian ini adalah pendekatan kuantitatif. Reka bentuk kajian yang digunakan adalah jenis reka bentuk kajian kes. Terdapat dua jenis data yang digunakan dalam kajian ini iaitu data primer dan data sekunder. Data primer kajian ini dikumpulkan melalui peralatan iaitu Global Positioning System (GPS). GPS digunakan untuk mendapatkan koordinat lokasi rumah pesakit. Jenis kawasan penempatan pesakit yang terlibat adalah taman perumahan, kampung, dan asrama institusi pengajian tinggi.

Data sekunder kajian ini pula dibahagi kepada dua iaitu kajian perpustakaan dan pengambilan data daripada jabatan kerajaan. Kajian perpustakaan melibatkan rujukan daripada kenyataan akhbar jabatan kesihatan, jurnal, buku, surat khabar dan lain-lain. Data daripada jabatan kerajaan dikumpulkan daripada Jabatan ukur dan Pementaan Malaysia (JUPEM) untuk mendapatkan data topografi Bahagian Mukah dan Pejabat Kesihatan Bahagian Mukah bagi memperoleh data pesakit. Data pesakit kajian melibatkan jenis data yang bersifat ordinal dan interval untuk dianalisis seperti data umur, bangsa, jantina, alamat dan jenis tuberkulosis. Data kajian ini telah mendapat kelulusan daripada Jawatankuasa Etika dan Penyelidikan Perubatan, Kementerian Kesihatan Malaysia. Kajian telah didaftar di National Medical Research Registeration (NMRR-18-555-40680).

\section{Data kajian}

Kajian ini melibatkan seramai 30 orang pesakit tuberkulosis di daerah Mukah. Jantina lelaki adalah lebih tinggi berbanding dengan jantina perempuan. Jantina lelaki adalah seramai 76.7 peratus manakala jantina perempuan adalah seramai 23.3 peratus (Jadual 1). Bagi kategori umur pula, pesakit tuberkulosis adalah dalam lingkungan 18 tahun hingga 73 tahun. Pesakit di bawah umur 18 tahun tidak mempunyai kes tuberkulosis.

Jadual 2: Data pesakit tuberkulosis tahun 2017

\begin{tabular}{|c|c|}
\hline Perkara & Jumlah (\%) \\
\hline \multicolumn{2}{|l|}{ Umur: } \\
\hline $18-29$ & $10(33.3 \%)$ \\
\hline $30-40$ & $5(16.6 \%)$ \\
\hline $41-51$ & $2(6.6 \%)$ \\
\hline $52-62$ & $7(23.1 \%)$ \\
\hline $63-67$ & $6(19.9 \%)$ \\
\hline \multicolumn{2}{|l|}{ Jantina: } \\
\hline Lelaki & $23(76.7 \%)$ \\
\hline Perempuan & $7(23.3 \%)$ \\
\hline \multicolumn{2}{|l|}{ Bangsa: } \\
\hline Melanau & $15(50 \%)$ \\
\hline Cina & $1(3.3 \%)$ \\
\hline Bidayuh & $1(3.3 \%)$ \\
\hline Iban & $10(33.4 \%)$ \\
\hline Lain peribumi & $1(3.3 \%)$ \\
\hline Bukan warganegara & $2(6.7 \%)$ \\
\hline \multicolumn{2}{|l|}{ Jenis: } \\
\hline PTSP & $19(63.3 \%)$ \\
\hline PTSN & $6(20 \%)$ \\
\hline ЕРТВ & $5(16.7 \%)$ \\
\hline
\end{tabular}

Di samping itu, bangsa Melanau merupakan bilangan kes tuberkulosis yang tinggi dengan mencapai seramai 15 orang (Jadual 2). Seterusnya diikuti oleh bangsa Iban yang mencapai 10 orang dan bukan warganegara iaitu sebanyak dua orang. Selain itu, bangsa Cina, Bidayuh dan lain-lain mencapai bilangan yang rendah di mana hanya terdapat satu orang pesakit bagi setiap bangsa tersebut. 
Sehubungan dengan itu, bilangan pesakit bagi jenis Pulmonary Tuberculosis Smear Positive (PTSP) mencapai bilangan kes yang tertinggi sebanyak 19 kes (Jadual 1). Seterusnya diikuti oleh Pulmonary Tuberculosis Smear Negative (PTSN) yang mencapai sebanyak enam kes. Manakala jenis Extrapulmonary Tuberculosis (EPTB) mempunyai bilangan kes rendah dan mencapai sebanyak lima kes di daerah Mukah.

\section{Teknik analisis GIS}

Dalam kajian ini melibatkan tiga jenis analisis iaitu analisis Mean Center, analisis titik panas (Hot Spot Analysis) dan analisis Moran'I. Perisian GIS seperti Arcmap 10.3 digunakan untuk menjalankan analisis taburan penyakit tuberkulosis di daerah Mukah. Tujuan GIS digunakan untuk mengenal pasti taburan dan kawasan titk panas bagi taburan tuberkulosis di daerah Mukah.

\section{Mean Center}

Teknik analisis pusat purata digunakan dalam kajian ini untuk mencari pusat purata bagi penyakit tuberkulosis yang berlaku di Mukah. Entiti titik akan mewakili rumah pesakit bagi menghasilkan titik pusat purata. Analisis ini juga boleh dikenali sebagai pusat graviti bagi mewakili kesemua entiti titik yang terdapat di sesuatu lokasi.

\section{Moran's I}

Analisis Moran'I ini merupakan analisis statistik yang telah lama diperkenalkan dalam bidang GIS. Analisis ini digunakan bagi zon atau titik yang mempunyai pemboleh ubah yang berterusan dalam sesuatu kajian. Penyelidik menggunakan analisis ini disebabkan ia mempunyai kelebihan dalam memaparkan autokolerasi ruang secara global (Ratchaphon, 2014). Penggunaan analisis ini membolehkan penyelidik mengenal pasti corak penyakit tuberkulosis di Mukah sama ada ia berbentuk berkelompok, rawak atau berselerak.

\section{Hot Spot Analysis (Getis-Ord Gi*)}

Penggunaan analisis Hot Spot Analysis (Getis-Ord Gi*) adalah bertujuan untuk mengenal pasti kawasan titik panas kes tuberkulosis yang terdapat di Mukah. Analisis ini sangat sesuai untuk menentukan kawasan tumpuan kajian tersebut terutama sekali apabila kajian melibatkan kawasan yang besar (Eboy et al., 2021). Analisis ini akan menggunakan jenis tuberkulosis sebagai angkubah. Melalui analisis ini akan menghasilkan paparan peta yang menggunakan lima kategori warna bagi mewakili lokasi titik panas penyakit tuberkulosis di Mukah.

\section{Hasil Kajian dan Perbincangan}

Hasil kajian ini telah menunjukkan bahawa jantina lelaki adalah lebih banyak berbanding dengan jantina perempuan iaitu sebanyak $76.7 \%$. Umumnya kaum lelaki digambarkan lebih suka merokok berbanding kaum wanita (Kefyalew et al., 2017); di mana, dalam laporan Kementerian Kesihatan Malaysia (2015) turut menyatakan jumlah perokok lelaki adalah tinggi. Sikap merokok antara jantina lelaki mendorong mereka dijangkit oleh penyakit tuberkulosis (Rhanim et al., 2015: WHO, 2018). Faktor pekerjaan seperti kerja kilang dan ladang sangat mempengaruhi kes tuberkulosis; di mana, pekerjaan ini kurang menitikberatkan persekitaran yang kondusif dan ianya sangat terdedah kepada persekitaran yang tidak sihat (Yih Yuan et al., 2017; Abdul Rauf et al., 2017). Selain itu, pemilik ladang gemar mengupah pekerja warga asing kerana kos upah yang ditawarkan adalah rendah (Siti Rohayu et al., 2014). Peningkatan jumlah pekerja warga asing turut mempengaruhi kes tuberkulosis kerana menurut Az Adibah (2018) lagi, pekerja warga asing umumnya mempunyai pengetahuan yang rendah terhadap simptom penyakit tuberkulosis. 
DOI: https://doi.org/10.47405/mjssh.v7i1.1256

Dari segi kategori umur pula, hasil dapatan kajian mendapati bahawa golongan yang berumur 52-73 tahun merupakan pesakit tuberkulosis yang paling banyak di Bahagian Mukah. Sistem imum badan yang lemah terutamanya bagi golongan tersebut memudahkan mereka dijangkit atau menghidap penyakit tuberkulosis (Az Adibah, 2018). Keadaan menjadi lebih kritikal apabila seseorang individu daripada golongan tersebut mempunyai penyakit kronik yang lain (Hajah Ummi, 2017). Situasi tersebut menyebabkan daya tahanan badan menjadi semakin lemah. Apabila daya tahanan badan seseorang individu tersebut semakin menurun; maka, keadaan tersebut membawa maut kepada individu tersebut.

Di samping itu, dari segi etnik pula dipengaruhi oleh faktor pola penempatan etnik yang berbeza. Hasil dapatan didapati bahawa ramai pesakit etnik Iban terletak di kawasan pendalaman. Manakala, taburan pesakit etnik Melanau pula terletak di kawasan bandar dan pinggir bandar yang berdekatan dengan muara dan tepi Sungai Batang Mukah. Menurut Juliza (2007), penempatan etnik Iban yang sememangnya sejak dahulu lagi kebanyakan etnik Iban tinggal di rumah panjang yang terletak di kawasan pendalaman. Menurut Yasir (1987) pula, kebanyakan penempatan komuniti Melanau adalah terletak di kawasan muara sungai dan anak sungai; di mana, terletak di kawasan persisiran dari Rajang sehingga Daerah Bintulu yang meliputi Bahagian Mukah (Tengku Intan et al., 2014). Keadaan ini jelas menunjukkan bahawa faktor pola penempatan etnik mempengaruhi taburan tuberkulosis di daerah Mukah.

Hasil kajian juga dipaparkan mengikut jenis tuberkulosis, iaitu Pulmonary Tuberculosis Smear Positive (PTSP), Pulmonary Tuberculosis Smear Negative (PTSN), dan Extrapulmonary Tuberculosis (EPTB). Berdasarkan rajah 2, menunjukkan bahawa PTSP meliputi sebahagian besar kawasan Daerah Mukah; manakala, PTSN dan EPTB pula hanya terdapat di sebahagian kecil di kawasan bandar dan kawasan luar bandar Mukah. Jika lihat dari sudut jumlah kes tuberkulosis adalah tinggi di kawasan bandar, manakala kawasan luar bandar pula mempunyai kes tuberkulosis yang rendah.

Rajah 2: Taburan tuberkulosisi mengikut jenis tuberkulosis di daerah Mukah.

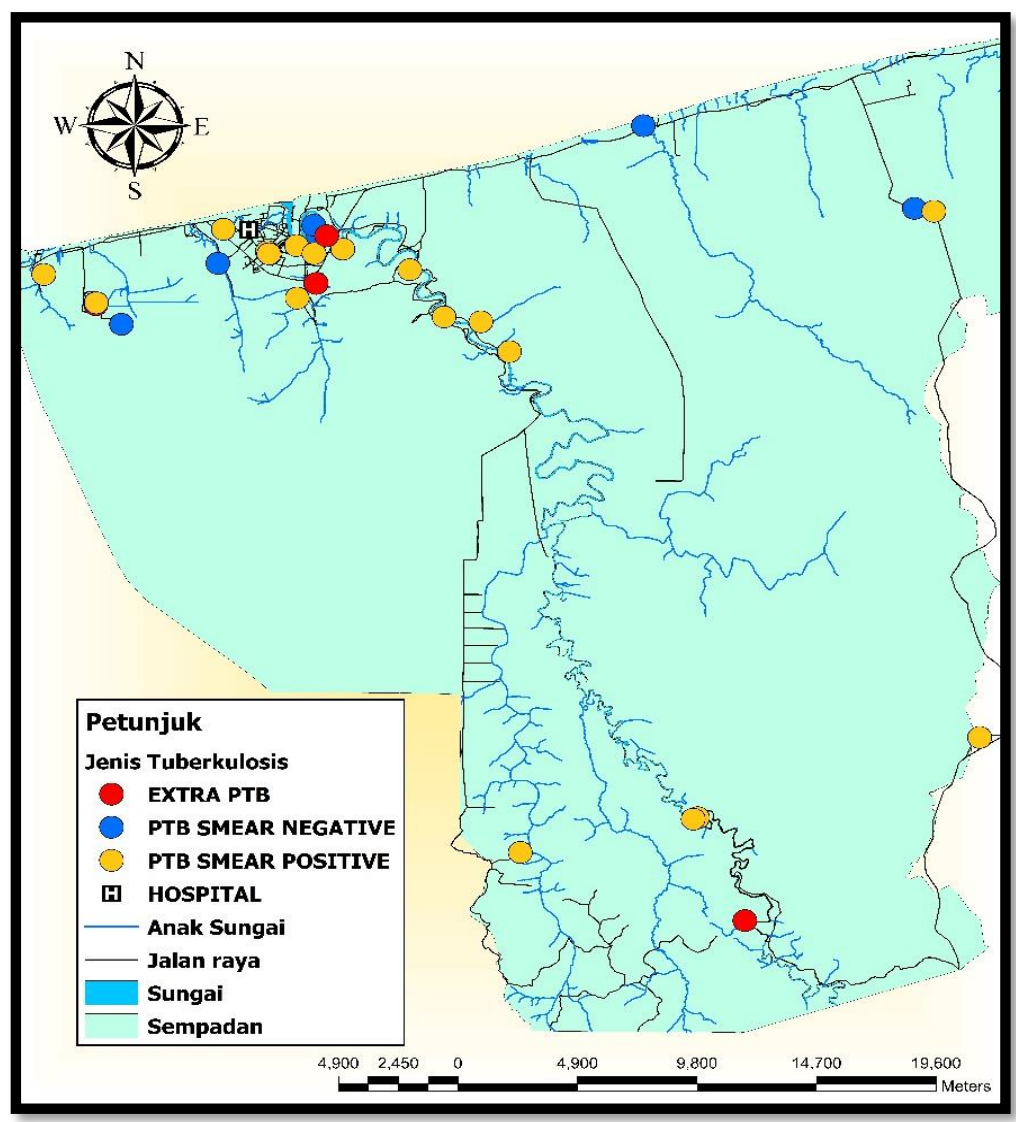


Di samping itu, didapati kawasan mean center penyakit tuberkulosis adalah terletak di kawasan pinggir bandar Mukah iaitu simbol segi tiga yang berwarna kuning (rujuk rajah 3). Hal ini disebabkan kebanyakan kes adalah terletak di kawasan bandar Mukah berbanding di kawasan luar bandar.

Rajah 3: Hasil analisis mean center bagi pesakit tuberculosis di daerah Mukah.

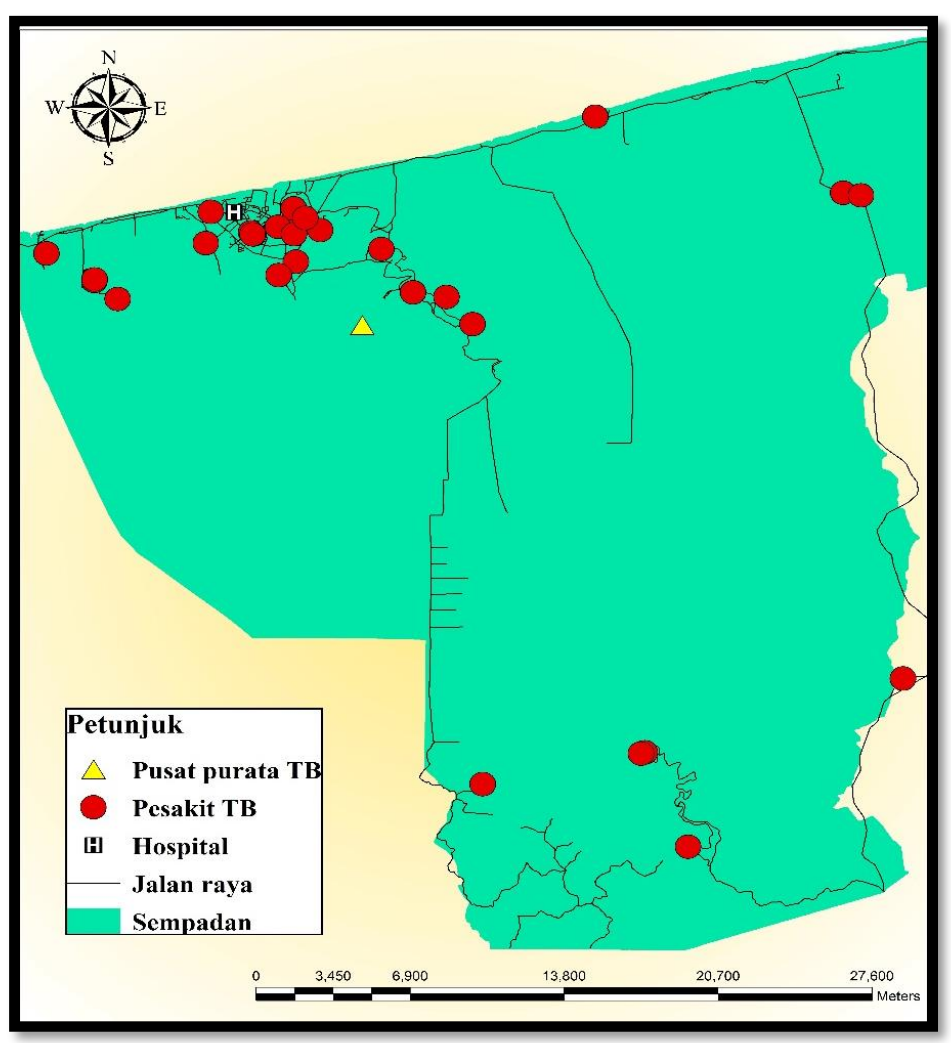

Sehubungan dengan itu, analisis Moran'I telah dianalisis berdasarkan taburan tuberkulosis di daerah Mukah. Hasil paparan analisis ini telah menunjukkan bahawa corak taburan tuberkulosis di kawasan daerah Mukah adalah secara rawak; di mana, nilai indeksnya adalah -0.451131 dan nilai z-score pula adalah sebanyak -0.880390 (rujuk rajah 4 di bawah).

Rajah 4: Paparan analisis Moran'I bagi taburan tuberkulosis di daerah Mukah.

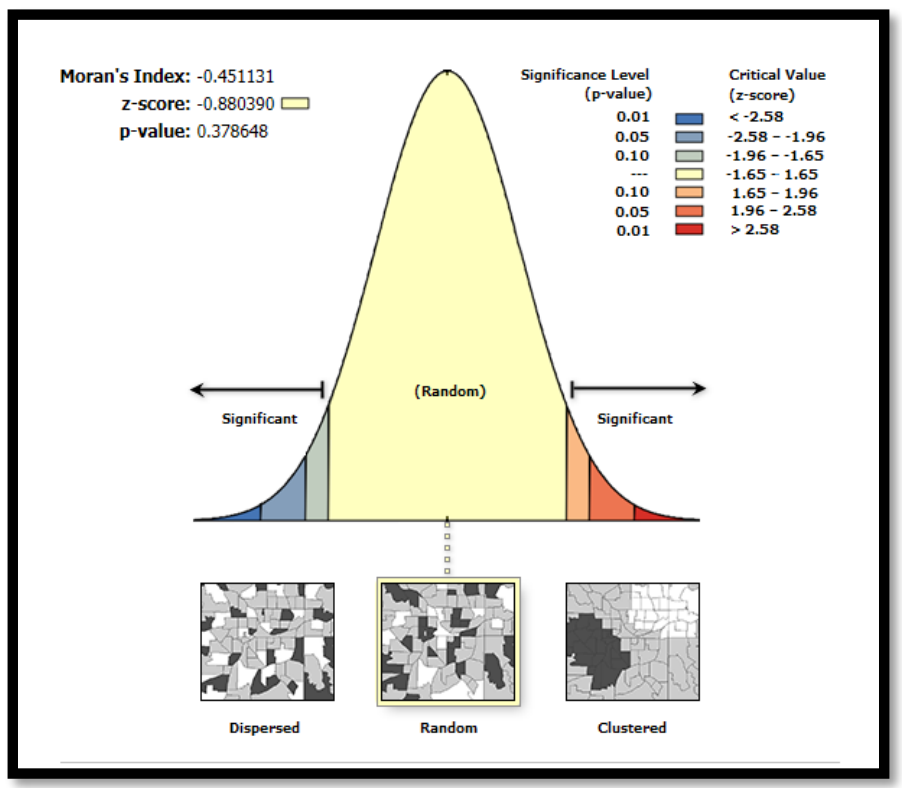


Seterusnya, analisis hot spot pula, didapati nilai z-score paling tinggi bagi kawasan titik panas adalah 0.410691-1.392579; manakala, nilai z-score paling rendah bagi titik kawasan sejuk adalah -1.005980 -0.705756 (rajah 5). Berdasarkan analisis tersebut didapati bahawa kawasan titik panas terletak di kawasan berhampiran dengan bandar Mukah. Lokasi-lokasi yang terangkum sebagai kawasan titik panas yang mana nilai z-score terdiri daripada 0.141863 hingga 1.392579 adalah terdiri daripada institut pengajian tinggi awam, Kampung Judan, Desa Merpati, Kampung Petanak, dan Kampung Bedanga. Hal ini disebabkan kawasan-kawasan tersebut terletak di kawasan berhampiran di bandar Mukah yang mana mempunyai tumpan orang ramai. Menurut Az Adibah (2018), beliau menjelaskan bahawa kes tuberkulosis yang tinggi di kawasan bandar disebabkan bandar merupakan tumpuan orang ramai. Tambahan beliau lagi, pembukaan cawangan institut pengajian tinggi awam seperti Politeknik Mukah dan Universiti Teknologi Mara (UiTM) mendorong orang ramai untuk melanjutkan pembelajaran di bandar Mukah. Keadaan ini menggalakkan berlakunya migrasi secara besar-besaran daripada kawasan lain menuju ke Daerah Mukah. Berkemungkinan besar terdapat antara migrasi tersebut mempunyai penyakit tuberkulosis pada asalnya dan membawa penyakit tersebut ke Mukah (Az Adibah, 2018).

Rajah 5: Lokasi titik panas bagi jenis kategori tuberkulosis di daerah Mukah.

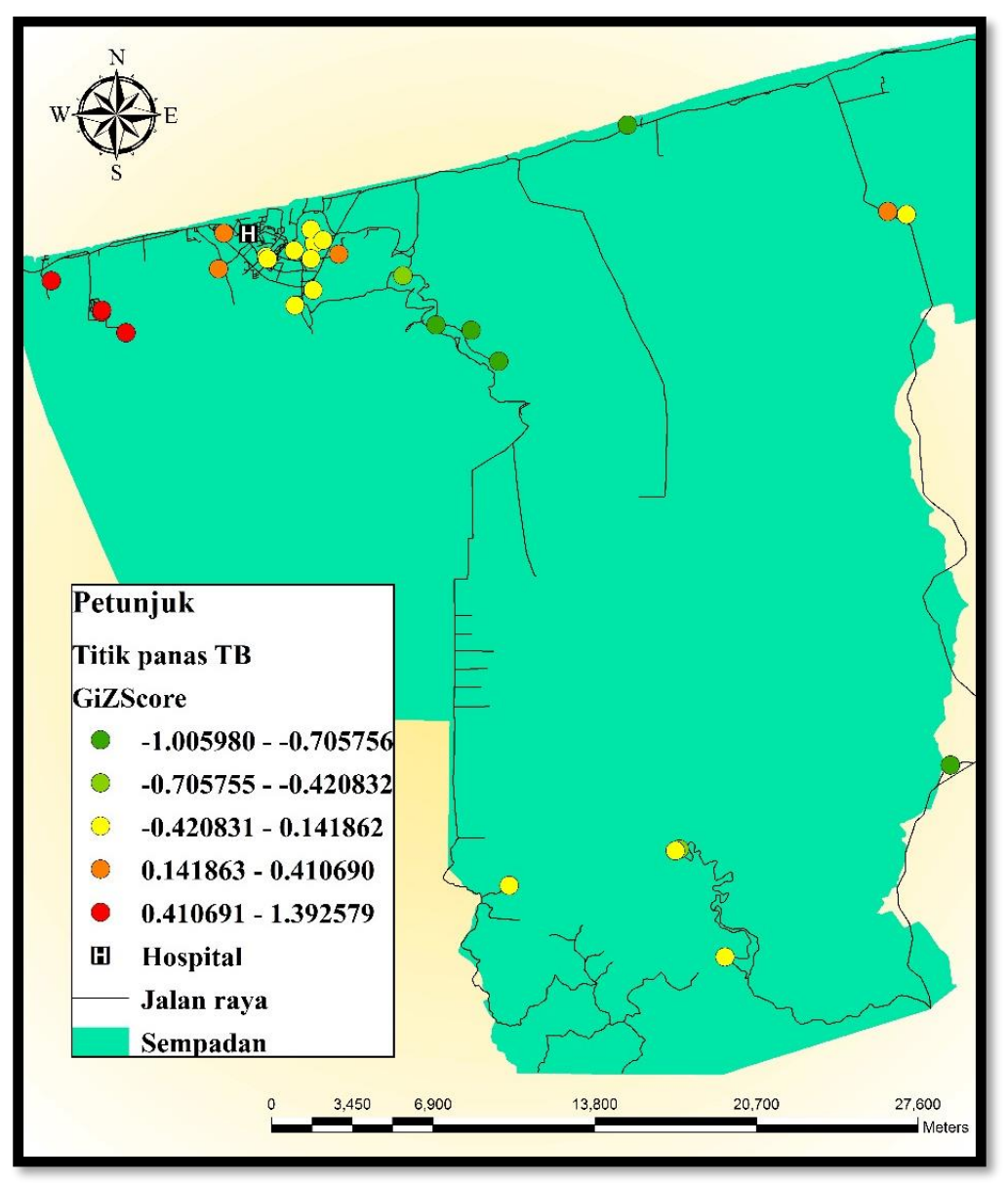

Manakala bagi kawasan titik sejuk yang mengandungi nilai -0.420832 hingga -1.005980 pula terletak di kawasan luar bandar iaitu Rumah Selai, Kampung Penipah, Kampung Teh, Kampung Tabo, Kampung Teh Labak dan Kampung Tegak. Keadaan ini telah dijelaskan oleh Az Adibah (2018) menyatakan bahawa kes yang rendah tidak merujuk kepada tiadanya kes tuberkulosis; jika melakukan pemeriksaan akan didapati masih ramai penduduk menghidap penyakit tuberkulosis. Tambah beliau lagi, penduduk luar bandar disebabkan sukar untuk mengakses ke pusat rawatan menyebabkan mereka kurang maklumat tentang penyakit tuberkulosis seperti rawatan tuberkulosis adalah percuma, mendapat skim bantuan kewangan, penyakit tuberkulosis dapat sembuh dan sebagainya. Keadaan ini telah menyebabkan mereka terlepas peluang yang baik untuk merawat penyakit ini dan menyebabkan 
seseorang individu tersebut meninggal dunia. Secara tidak langsung, ketiadaannya rekod mereka dalam sistem pangkalan data hospital Mukah.

Lebih-lebih lagi,pegawai kesihatan mereka perlu melalui jarak perjalanan yang jauh dan kos pengangkutan yang tinggi (Az Adibah, 2018). Tambahan pula, Pegawai kesihatan (2018), menyatakan terdapat pesakit yang terpaksa menggunakan mod pengangkutan air seperti bot laju atau sampan sebelum dapat menggunakan pengangkutan darat untuk sampai ke hospital. Faktor seperti sistem mod pengangkutan dan topologi mempengaruhi darjah ketersampaian yang rendah dan mempengaruhi kekerapan pesakit ke hospital untuk menerima rawatan (Pengqian et al., 2014; Huairen dan Hyun Kim, 2014; B. Recheal et al., 2016; Courtnee et al., 2017). Ekoran daripada darjah ketersampaian yang rendah menyebabkan pesakit tidak dapat rawatan secara segera pada peringkat awal dan tahap penyakit tuberkulosis menjadi kritikal. Kemungkinan besar pesakit mengalami kelewatan mendapat rawatan berdasarkan jadual yang telah ditetapkan (Ching et al., 2007).

\section{Kesimpulan}

Penggunaan Sistem Maklumat Geografi (GIS) membolehkan seseorang penyelidik mengenal pasti corak taburan tuberkulosis yang terdapat di kawasan daerah Mukah. Hal ini kerana GIS bertindak sebagai salah satu peralatan elektronik sistem suvelan dalam bidang perubatan. Kepentingan bagi mengenal pasti corak taburan tuberkulosis bagi membolehkan sesuatu tindakan pencegahan dilaksanakan dengan lebih sistematik dan berkesan. Tindakan pengawalan penyakit tuberkulosis adalah untuk mencegah penyebaran penyakit ini dan penting dalam penyediaan peruntukan oleh para pembuat keputusan. Tambah lagi dengan adanya sumber manusia yang berkemahiran tinggi tinggi dalam penggunaan GIS membolehkan sistem suvelan ini bertindak secara lebih berkesan dan menyeluruh. GIS boleh diguna pakai oleh jabatan-jabatan yang terlibat bagi mengaplikasikan terhadap semua urusan yang berkaitan dengan jagaan kesihatan di Malaysia. Tuntasnya, GIS sebagai satu peralatan kepada sistem suvelan dalam bidang perubatan maka tahap kesihatan rakyat akan lebih terjamin.

\section{Rujukan}

Abdul Rauf Abdul Rasan, Noresah Mohd Shariff, Jiloris F. Dony \& Punitha Makeswaran. (2017). Mapping Risk Areas of Tuberculosis Using Knowledge-Driven GIS Model in Shah Alam, Malaysia. Pertanika Journals Social Sciences \& Humanities, 25(s),135-144.

Akaninyene Asuquo Otu. (2013). Is the directly observed therapy short course (DOTS) an effective strategy for tuberculosis control in a developing country?. Asian Pacific Journal of Tropical Disease, 3(3),227-231.

Androula Pavli \& Helena Maltezou. (2017). Health Problens of Newly Arrived Migrants and Refugees in Europe. Journal of Travel Medicine, 1-7.

Bernd Recheal, Aleksandar Dzakula, Antonio Duran, Giovanni Fattore, Nigel Edwards, Michel Grignon, Marion Haas, Triin Habicht, Gregory P. Marchildon, Antonio Moreno, Walter Ricciardi, Louella Vaughan \& Tina Anderson Smith. (2016). Hospitals in Rural or Remote Areas: An Exploratory Review of Policies in 8 Hight-income Countries. Science Direct, 758-769.

Ching Thon Chang \& Adrian Esterman. (2007). Diagnostic Delay Among Pulmonary Tuberculosis Patients in Sarawak, Malaysia: A Cross-Sectional Study. The International Journal of Rural Health Research, Education, Practice and Policy, 2, 667:1-8.

Courtnee Melton, Laura Berlind, Mandy Pellegrin \& Brains Straessle. (2017). How Transportation Impacts Public Health. The Sycamore Institute. 1-4.

Az Adibah Zubairi. (2018). Darjah Ketersampaian Bagi Pesakit Tuberkulosis ke Pusat Perkhidmatan Kesihatan. 29 Oktober.

Eboy, O. V., Karim, H., \& Kalang, L. (2021). Mapping the Potential Pattern of COVID-19 Disease Risk Using Spatial Analysis in Kota Kinabalu, Sabah. Transaction on Science and Technology, 8(3-3), 408-418.

Eboy, O. V., (2017). Tourism Mapping: An Overview of Cartography and the Use of GIS. BIMPEAGA Journal for Sustainable Tourism Development, 6(1), 61-67. 
Fernanda Monteiro de Castro Fernandes, Eder de Souza Martins, Daniella Melo Arnaud Sampaio Pedrosa \& Maria do Socorro Nantua Evangelista. (2017). Relationship Between Climate Factors and Air Quality With Tuberculosis in the Federal District, Brazil, 2003-2012. The Brazilian Journal of Infectious Disease. 21(4):369-375.

Hajah Ummi Nadiah Binti Yusoff. (2017). Kepentingan rawatan tibi terhadap kesihatan. Daripada : http://www.myhealth.gov.my/kepentingan-rawatan-tibi-terhadap-kesihatan/

Haikun Qian, Da Huo, Xiaoli Wang, Lei Jia, Xitai Li, Jie Li, Zhiyong Gao, Baiwei Liu, Yi Tian, Xiaona Wu dan Quanyi Wang. (2016). Detecting Spatial-Temporal Cluster of Hand, Foot and Mouth Disease in Beijing, China 2009-2014. Journal of Geospatial Health, 8(3),102 - 115.

Huairen Ye \& Hyun Kim. (2014). Measuring Spatial Health Disparity Using a Network-Based Accessibility Index Method in a GIS Environment: A Case Study of Hillsborough County, Florida. International Journal of Geospatial and Environmental Research, 1(1),1-22.

J. Kim. (2014). Is Ambient Air Pollution Another Risk Factor of Tuberculosis?. Korean J Intern Med. 29, 170-172.

Juliza Anak Kennedy. (2007). Khazanah warisan masyarakat etnik Iban di Sarawal: Satu kajian dokumentasi harta intelek. Fakulti Seni Gunaan dan Kreatif. Universiti Malaysia Sarawak.

Kefyalew Addis Alene, Kerri Viney, Emma S. McBryde \& Archie C. A. Clements. (2017). Spatial Pattern of Multidrug Resistants Tuberculosis and Relationships to Socia-Economic, Demographic and Household Factors in Northwest Ethiopia. Journal Pone, 1-14.

Kementerian Kesihatan Malaysia. (2015). Report on Smoking Stutus Among Malaysian Adults.

Kok-Lim Alvin Yau, Sian Lun Lau, Hui Na Chua, Mee Hong Ling, Vahad Iranmanesh, Shwu Chen Charis Kwan. 2016. Greater Kuala Lumpur as a Smart City: A Case Study on Technology Opportunities. International Conference on Knowledge and Smart Technology. 8:-6.

Malclom D. Kearns. (2014). The role of vitamin D in tubeculosis. Journal of Clinical \& Translational Endocrinology, 1,67-169.

M Muniyandi dan Rajeswari Ramachandran. (2018). Socioeconomic inequalities of tuberculosis in India. Epert Opinion on Pharmocotherapy, 9(10),1623-1628.

Mohd Faiz Bin Mohd Yaakob \& Jamal @ Nordin Bin Yunus. (2017). Penularan Penyakit Tuberculosis (TB) di Malaysia: Amalan Pencegahan dan Mekanisme Pengawalan di Institusi Pendidikan. Jurnal Sains dan Kesihatan Malaysia, 15(1), 131-134.

Mohd Hazrin, Helen Guat Hiong, Nadzri Jai, Norzawati Yeop, Muhammad Hatta, Faizah Paiwai, S. Joanita \& W. Othman. (2016). Spatial distribution of dengue incidence: A case study in Putrajaya. Journal of Geographic Information System, 8, 89-97.

Norfazila Ab. Hamid \& Rahim Aman. (2016). Varian Melanau Sarawak: Tinjauan di Melanau Mukah. Jurnal Melayu, 15(1), 99-112.

Norazman Mohd Rosli, Shamsul Azhar Shah \& Mohd Ihsani Mahmood. (2018). Gegraphical Information System (GIS) application in Tuberculosis Spatial Clustering Studies: A Systematic Review. Malaysian Journal of Public Health Medicine, 18(1),70-80.

Olivia Oxlade dan Megan Murray. (2012). Tuberculosis and poverty: Why are the poor at greater risk in India?. PLOS, 7(11):1-8.

Pearce J. (2007). Incorporating Geographies of Health Into Public Policy Debates: The GeoHealth Laboratiry. New Zealand Geographer, 63(1):149-153.

Pengqian Fang, Shilong Han, Lu Zhao, Zi Fang Yang Zhang \& Xiaoxu Zou. (2014). What limits the Utilization of Health Services Among the Rural Population in the Dabie Mountains- Evidence from Hubei Province, China?. BMC Health Service Research, 14(379): 1-7.

Portal Rasmi RECODA. 2018. http://www.recoda.com.my

Ratchaphon samphutthanon, Nitin kumar Tripathi, Sarawut Ninsawat \& Raphael Duboz. (2014). Spatiol-Temporal Distribution and Hotspot of Hand, Food and Mouth Disease (HFMD) in Northern Thailand. International Journal of Environmental Reasearch and Public Health, 8(11): 312-336.

Shamsul Azhar Shah, Md. Idris Mohd. Nor, Abdul Hadi Harman Shah \& Tahir Aris. (2002). Penggunaan Aplikasi GIS dalam Penyakit Tuberkulosis di Cheras, Kuala Lumpur, Malaysia. Malaysian Journal of Public Health Medicine, 2(2), 15-26.

Siti Rohayu Norsi'ee, Rahmah Ismail dan Norlin. (2014). Impak Pekerja Asing Terhadap Upah Firma Perusahaan Kecil Sederhana Sektor Pembuatan di Malaysia. Prosiding PERKEM Ke-9. 104-116. 
Trevor. J. B. Dummer. (2008). Health Geography: Supporting Public Health Policy and Planning. Canadian Medical Association Journal, 178(9):1177-1180.

Tengku Intan Zarina Bt Tengku Puji, Mazlan Bin Ibrahim, Zaimuariffudin Shukri Bin Nordin, Ibtisam Bt Abdullah, Noriza Bt Salleh dan Munirah Binti Abd Ghani. (2014). Kepercayaan etnik Melanau dari sudut pandang Islam: Suatu analisa. E-Proceeding of the World Conference on Integration of Knowledge. 141-147.

Trevor. J. B. Dummer. (2008). Health Geography: Supporting Public Health Policy and Planning. Canadian Medical Association Journal, 178(9):1177-1180.

Utusan Borneo. 2018. Kajian Bangun Rumbia. https://www.pressreader.com/malaysia/utusan-borneosarawak/20180114/281509341589606

WHO. (2015). Migration Health:Key issues. http://www.euro.who.int/_data/assets/pdf_file/0005/293270/Migration-Health-Key-Issues.pdf?ua $=1 \& u a=1$

WHO. (2018). Smoking and Tuberculosis: a Dangerous Combination. http://www.euro.who.int/en/health-topics/communicablediseases/tuberculosis/news/news/2018/3/smoking-and-tuberculosis-a-dangerous-combination

Yih Yuan Chen, Jia Ru Chang, Chih Da wu, Yen Po Yen Shiu ju Yang, Chih Hao Hsu, Ming Ching Lin, Ching Fsng Tsai, Ming Shian Lin, Ih Jen Su \& Horng Yunn Dou. (2017). Combining Molecular Typing and Spatial Pattern Analysis to Identify Areas of High Tuberculosis Transmission in a Moderate-Incidence County in Taiwan. Scientific Reports. 1-8.

Yuan-qing Zheng, Youssef W. Naguib, Yixuan Dong, Yan-chun Shi, Shorgan Bou dan Zhengrong Cui. (2015). Application of bacillus Calmette-Guerin and recombinant bacillus Calmette-Guerin in vaccine development and tumor immunotherapy. PMC, 14(9), 1255-1275.

Yunxia Liu, Xianiun Wang, Chunkun Pang, Zhongshang Yuan, Hongkai Li, dan fuzhong Xue. (2015). Spatio-temporal Analysis of the Relationship Between Climate and Hand, Foot and Mouth Disease in Shangdong Province, China. 2008-2012. Journal of BMC Infectious Diseases, 15(146), 1-8. 